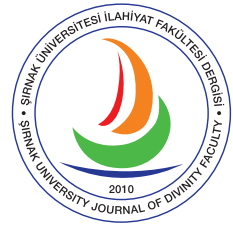

Şırnak University Journal of Divinity Faculty Vol.: 11, Issue: 24, June 2020

e-ISSN 2667-6575

\title{
Türk ve Arap Mitolojisinin Ortak ve Özgün Figürleri
} Common and Original Elements of Turkish and Arabian Mythology

\section{Selman Yeşil}

Dr. Öğr. Üyesi, Siirt Üniversitesi, Yabancı Diller Yüksekokulu, Arapça Mütercim ve Tercümanlık Bölümü Assistant Professor, Siirt University, School of Foreign Languages, Department of Translation and Interpreting Siirt, Turkey syesil4@hotmail.com https://orcid.org/0000-0002-5885-0302

\section{Makale Bilgisi / Article Information}

Makale Türü / Article Types: Araştırma Makalesi / Research Article

Geliş Tarihi / Received: 13 Şubat / February 2020

Kabul Tarihi / Accepted: 16 Mart / March 2020

Yayın Tarihi / Published: 15 Haziran / June 2020

Cilt / Volume: 11 Sayı / Issue: 24 Sayfa / Pages: 368-392

Atıf / Cite as: Yeşil, Selman. "Türk ve Arap Mitolojisinin Ortak ve Özgün Figürleri [Common and Original Elements of Turkish and Arabian Mythology]". Şırnak Üniversitesi İlahiyat Fakültesi Dergisi-Şırnak University Journal of Divinity Faculty 11/24 (June 2020), 368-392 https://doi.org/10.35415/sirnakifd.693513

Etik Beyanı / Ethics Declaration: Bu makalede bilimsel araştırma ve yayın etiği ilkelerine riayet edilmiştir. Makale etik izin gerektirmeyen bir çalışma olup en az iki hakem tarafından incelenmiş ve intihal içermediği teyit edilmiştir./ In this article, the principles of scientific research and publication ethics are respected. The article is a study that does not require ethical permission. It has been reviewed by at least two referees and was confirmed that it did not contain plagiarism.

Copyright () Published by Şırnak Üniversitesi, İlahiyat Fakültesi / Şırnak, Türkiye (Şırnak University, Faculty of Divinity, Şırnak, 73000 Turkey). 


\title{
Öz
}

Mitoloji, 'insanoğlunun doğa olaylarını ve metafizik âlemini anlama ve anlamlandırma amaçlı anlatıları' olarak özetlenebilir. Mitolojinin, kültürel gelişmişlik seviyelerine bakmaksızın hemen hemen tüm toplumların başvurduğu bir yöntem olduğunu söylemek mümkündür. Mitolojinin temel özelliği, aykırı ve zıt olguların tek varlıkta birleştirilmesi veya bir varlığın alışagelmişin dışında tasvir edilmesidir. Tarih boyunca iç içe yaşayan, dinî, ticarî ve sosyal birçok ortak paydaları bulunan Araplar ve Türkler, mitolojiyi etkin şekilde kullanmıştır. Bin yılı aşkın süredir aynı dini benimseyen, coğrafî olarak da yakın olan Türkler ve Araplar, dil, kültür ve yaşam biçiminin yanı sıra mitolojik unsurlarda da karşılıklı etkileşime maruz kalmışlardır. Bu etkileşimin doğal bir neticesi olarak da özgün figürlerinin yanı sıra ortak figürler de oluşmuştur. İnsanlık tarihinin bir bütün olarak tanınması ve dünya milletlerinin mitolojik anlatılarının insanlığın kültürel mirası içerisindeki konumunun anlaşılması için karşılaştırmalı mitoloji araştırmalarının önemi her geçen gün artmaktadır. Etkileşimlerini görmek amacıyla çalışmamızda derin ilişkilere sahip olan Türklerin ve Arapların mit anlayışlarına değinilecek, özgün mitolojik figürleri tanıtılacak ve İslam dini ile tanışmalarının ardından her iki toplumun mit anlayışında ortaya çıkan ortak figürlere ve yaşanan değişime de yer verilecektir.

Anahtar Kelimeler: Arap Edebiyatı, Mitoloji, Türk Mitolojisi, Arap Mitolojisi, Kutsal, Efsane, Put, Kâhin.

\begin{abstract}
Mythology can be encapsulated as narratives endeavouring to clasp the natural phenomena and the metaphysical realm of mankind. While this method is distinctive in primitive societies, it is also recoursed by civilized societies. The main feature of mythology is the unification of antithetical phenomena in a single embodiment or the depiction of an entity outside the box. Arab and Turkish societies having lived throughout history on the common grounds of religious, commercial and social sharings have effectively utilized mythology. Moreover, they were subjected to the interaction in mythological beliefs as well as language, culture, and life. As a corollary of this interaction, besides the unique figures, common ones have emerged, as well. The importance of comparative study of mythology is ascending to recognize of the human history as a whole and to conceive the position of the mythological narratives of the world nations in the cultural heritage. Therefore, the mythological conceptions and figures will be introduced to see the reciprocal interaction between Turks and Arabs who had deep relations, and the changes and common figures in the myths of two nations after Islam will be indicated.
\end{abstract}

Keywords: Arabic Literature, Mythology, Turkish Mythology, Arabian Mythology, Holy, Myth, Idol, Seer. 


\section{Extended Abstract}

Mythology can be summarized as all of the narratives and beliefs in societies for understanding the natural events and metaphysical realm and giving meaning to them. It is a phenomenon found in almost all societies regardless of cultural development level. The main feature of mythology is to combine contradictory and opposite phenomena in one being or depiction of a being unusually. Undoubtedly, the only creature that lives in this universe is not human beings. Each of the creatures that live with human beings are equipped with various physical abilities to survive. However, human being is equipped with reasoning rather than physical equipment to fight against difficulties. Human being is the only creature with the desire to analyze the events and to reach a higher level.

While other creatures content with the level they had when they started life, thanks to the ability to reason, people succeeded to build civilizations, skyscrapers, to subjugate all other living creatures and use them in his service by getting over the level of life in the cave. However, despite all his talent and power, human being is amazed by the existence of events that surpass himself/herself in nature and cannot manage and direct it, and also despite himself/herself, he made an effort to understand the cause of the events that developed and to turn them in his/her favor or to protect himself/herself from their malignancy. As a result of this effort, each society has reached different results. In some societies, symbols of some of these results have been created and visualized. These images were sometimes chosen from inanimate beings and sometimes from living creatures. Human beings applied to these symbols to make the rain rain, which is one of their basic needs, to have fertilized crops, to develop unity and victory against the enemy, to reach peace in the after-life as well as for protection from the damage of lightning flashing, overflowing floods, raging waves in the sea and diseases in the society. As a result, mythology has developed in societies and has been used in many fields. Hero or superhuman figures have appeared; these figures also laid the groundwork for the emergence of fairy tales and legends.

As in many sociological events, there is a mutual interaction of societies in mythology. Since the discovery of the mysterious aspect of natural events and creation, making sense of life and determining its purpose are common areas that all humanity dwells on. Arabs and Turks, who have lived together in history and have many common denominators in the religious, commercial and social area, have effectively used mythology. The Turks and Arabs, who have adopted the same religion for more than a thousand years and are geographically close to each other, have been exposed to mutual interaction in mythological elements as well as language, culture, and lifestyle. As a natural result of this interaction, common figures were formed besides their original figures. The importance of comparative mythology research is increasing day by day for the recognizing the history of humanity as a whole and understanding the position of mythological narratives of the nations of the world in the cultural heritage of humanity. In our study, in order to see their interactions, the understanding of myths 
of Turks and Arabs, who have deep relations, will be welcomed, their original mythological figures will be introduced, and following their meeting with the religion of Islam, the common figures and the change that occurred in the understanding of myth of both communities will be included. Arabs include a nation, which survives today and originates in the oldest periods. Arabs are divided into two main groups by the historians: 'Arab-1 Bâide' (extinct/withdrawn from history scene) and 'Arab-1 Bâkiye' (those whose lineages continue/survivors). Arab-i Khaki whose lineage continues is originally based on the Prophet Abraham and they are the first in terms of number and expansiveness area of Sami tribes that are still alive. The language they speak is also the richest and most advanced one of the Sâmî languages. Although the phenomenon of mythology does not exactly match with the definition of mythology today, it was defined with the word "üstür/esâtır' by the Arabs in the classical period. The origin of the Turks, one of the most established nations in the world, is based on Prophet Noah's son Yafes, according to the general consent.

The oldest known homelands are the region between the north of the Altai mountains and the southwest of the Sayan mountains. When we look at the pre-Islamic Turkish mythology, it is seen that certain symbols such as the moon, star, water, fire, light, iron and gray wolf mentioned in epics are used as mythology elements. In addition to the original mythological figures, there are common figures in the Turks and Arabs. Metaphysical field is an area where myths are widely used. Within this context, while the idols are common in the Arabs, there are some mythological figures believed to be creative or to be tasked in any position in the Turks. Lat, Uzzâ, Hübel and Vedd are the most famous godly mythological figures of the Arabs. In the Turks, Kara Khan, who is accepted as the most authoritative god of the sky, Ulgen, who is considered to be the son of Kara Khan, Ak Ana who inspires to create the god of Ulgen, and Erlik Khan, who is accepted as the source and representative of evil, are the popular mythological figures. Arabs and Turks have some mythological figures that it is believed that they can give information about the future. While the Arabs called the people belonging to this structure as "soothsayer", the Turks called it "shaman". One of the beings in the mythological narratives of the Turks and Arabs is the jinn. Both in Arabs and Turks believe that the soothsayers and shamans, who predict the future, were in contact with the jinn. One of the areas with mythological figures in both societies are phenomenon of holy places and time. In the Arabs, Kaaba, Arafat Mountain and especially Masjid al-Aqsa, following the Islam, have been accepted as a sacred place all along. In Turks, Kaf Mountain, Golden Mountain and Ergenekon Mountain are the places considered sacred. As an example of holy time myths, Receb, Shaban, Ramadan and Muharram regarded as haram months in the Arabs, and they were regarded so after Islam as well. In addition, extraordinary people have also taken place in both communities mythologically. Some characters, such as Battal Gâzî, are mythological figures known and accepted by both Arabs and Turks. 


\section{GİRIŞ}

İnsan, bu evrende hayatını sürdüren tek canlı varlık değildir. Kendisiyle birlikte yaşayan canlıların her biri hayatını sürdürebilmek için çeşitli fiziki yetilerle donatılmıştır. Ancak insan zorluklara karşı mücadele için fiziki donanımdan ziyade akıl yetisiyle donatılmıştır. İnsanoğlu olayları ve şartları analiz edip daha iyi seviyeye gelme arzusuna sahip yegâne canlıdır. Diğer canlılar hayata başladıklarında sahip oldukları seviyeyle yetinirken, insan düşünme yeteneği sayesinde mağaradaki yaşam seviyesinden sıyrılarak medeniyetler kurmayı, gökdelenler dikmeyi ve diğer tüm canlıları boyunduruğu altına alıp hizmetinde kullanmayı başarmıştır. Ancak tüm bu yeteneğine ve gücüne rağmen doğada kendisini aşan ve yönlendirip yönetemediği olayların varlığı karşısında hayretler içerisinde kalan insan, kendisine rağmen gelişen olayların nedenini anlamaya ve bunları kendi lehine çevirmeye veya kötülüklerinden korunma çabasına girmiştir.

Bu çaba neticesinde her bir toplum farklı sonuçlara ulaşmıştır. Kimi toplumlarda bu sonuçların bir kısmının sembolleri oluşturulmuş ve görselleştirilmiştir. Bu görseller bazen cansız varlıklardan bazen de canlılardan seçilmiştir. İnsan bu sembollere temel ihtiyaçlarından olan yağmurun yağması, ektiği ekinin verimli olması, düşmana karşı birliğinin gelişmesi ve zafere ulaşması, ölüm sonrası hayatında huzura kavuşması amacıyla başvurduğu gibi çakan şimşeğin, taşan selin, denizdeki azgın dalgaların ve toplumdaki hastalıkların zararından korunma gayesiyle de başvurmuştur. Bunun neticesinde toplumlarda mitoloji gelişmiş ve birçok alanda kullanılır hale gelmiştir. Kahraman veya insanüstü güç sahibi figürler ortaya çıkmış; bu figürler de masalların ve efsanelerin ortaya çıkışına zemin hazırlamıştır. ${ }^{1}$

\footnotetext{
${ }^{1}$ Mit olgusu hakkında geniş bilgi için bk. Behçet Necatigil, 100 Soruda Mitologya (İstanbul:
} 
Köken olarak Yunancaya dayanan mit/myth'in, 'geleneksel olarak yayllan veya toplumun hayal gücünün etkisiyle biçim değiştiren alegorik bir anlatımı olan halk hikâyesi, efsaneleşen anlam veya kişi' anlamın ifade ettiği gibi 'bir ulusa, bir dine ya da uygarlğ̆a ait efsanelerin tümü'nü ifade ettiği iddia edilmiştir. ${ }^{2}$ Hakkında birçok yorum ve tanım yapılan mitoloji, uzmanları tarafından doğa olaylarının nedenlerini, hayvanların kökenini, toplumdaki törenlerin ve âdetlerin ortaya çıkışını ele alan, ya da tarihî olayları anlatan son olarak da macera ve eğlence amaçlı olan mitler olmak üzere üç kısımda incelenmiştir. ${ }^{3}$

Mitlerin incelenme şekli ve mitlere yaklaşım tarzı farklılık arz etse de mitolojik figürlerin temel ilkesi karşıtlık ve olağana aykırılık ve bir varlığın alışagelmişin dışında tasvir edilmesi veya emsalinde bulunmayan yetilerle donatılması olduğu söylenebilir. Başka bir deyişle bir canlının veya nesnenin kendi emsalinden ayrı görülmesidir. Şunu göz ardı etmemek gerekir ki mitlerin ait olduğu toplumda kabul görmesi onun gerçekliğine veya doğruluğuna kanıt teşkil etmez. Ancak bu gerçeklik mitlerin değerini azaltmaz. Zira mitler, içinden çıktıkları toplumun kültüründen ve tarihinden izler taşır. Toplumun edebi ve kültürel olarak gelişimine katkı sağladıkları gibi toplum tarihi hakkında bilgi edinmeye de imkân verirler. Bu nedenle safsata ve hurafe olarak görülüp göz ardı edilen mitlerin bu açılardan değerlendirilmesinin toplumların tanınmasına önemli katkı sunacağı inancındayız.

Bu çalışmamızda ele alacağımız mitoloji olgusunu -doğru veya yanlışlığına dair bir iddiada bulunmaksızın- Türk ve Arap toplumlarındaki konumu açısından ele alınacaktır. Bu bağlamda her iki toplumdaki mitlerin ortak paydaları ve bu ortak paydaların yaşamlarına yansımaları örnekler ışığında irdelenecektir.

\section{ARAPLARDA VE TÜRKLERDE MITOLOJI}

Araplarda mitoloji olgusuna değinmeden önce günümüzde varlıklarını sürdüren Arapların tarihsel gelişimine kısaca değinmek yerinde olacaktır. Tarihçiler Arapları öncelikle 'Arab-ı Bâide' (soyları tükenenler/ tarih sahnesinden çekilenler) ve 'Arab-ı Bâkiye' (soyları devam edenler/ varlıklarını sürdürenler) olmak üzere iki ana gruba ayırmaktadır. Soyları

Gerçek yayınevi, 1988), 3; Şefik Can, Klasik Yunan Mitolojisi (İstanbul: İnkilab Kitabevi, 1997), 1; Celal Beydili, Türk Mitolojisi Ansiklopedik Sözlük (Ankara: Yurt Kitap Yayın, 2005), 392-394; Karen Armstrong, Mitlerin Kısa Tarihi, çev. Dilek Şendil, ed. Cem Alpan (İstanbul: Merkez Kitapçllık, 2014), 9-25.

2 Türk Dil Kurumu Sözlü̆ğ̈̈, "Mit” (Erişim: 13.10.2019).

3 Mihâil Mesût, Esâtîr ve mu'tekadâtu'l-'Arab kablel-İslâm (Beyrut: Dâru'l-ilm li'l-melâyîn, 1994), 29-30; Fuzuli Bayat, Mitolojiye Giriş (İstanbul: Ötüken Neşriyat, 2013), 15-17. 
devam eden Arab-ı bâkiye, köken olarak Hz. İbrahim'e dayandırılırlar ve yaşamakta olan Sâmî kavimlerin sayı ve yayılış sahası bakımından birincisidirler. Konuş̧tukları dil de Sâmî dillerinin en zengini ve gelişmişidir. ${ }^{4}$

Arap tarihinin ilk devirleri hakkında detaylı bilgiye sahip değiliz. Eski devir tarihleri, Arap yarımadasının tarihiyle iç içe olan Arapların ana yurtlarının Arabistan olduğu ilim âlemince kabul edilmesine rağmen farklı görüş ileri sürenler de vardır. Büyük bir kısmının çöl olması sebebiyle oldukça güç olan arkeolojik araştırmalar yapılıncaya kadar bu konuda kesin bir şey söylemek zordur. Araplar hakkındaki en eski bilgiler komşu kavimlerin yazılı belgelerinden elde edilmektedir. ${ }^{5}$

Araplarda mitoloji olgusu günümüz mitoloji tanımıyla tam örtüşmese de üstür/esâtır kelimesi ile ifade edilir. Kur'ân'da da kullanılan bu kelime, köken olarak 'yazmak, çizmek, çizgi çekmek ve tanzim etmek' gibi anlamlara gelen (سطر) kökünden elde edilmiştir. ${ }^{6}$ Kureyşlilerin Hz. Muhammed'in tebliğ ettiği ilahi vahyi 'usture/esâtir' olarak niteleyip vahiy olmasından ziyade eskilerin birbirinden naklettikleri aslı astarı olmayan iddialar olduğunu öne sürmeleri, (bk. Furkân, 25/5) eski çağlarda dahi Araplar nezdinde mitolojik anlatıların revaçta olduğuna dair bir kanıt olarak görülebilir. Araplarda esâtir olgusu, hayali anlatılar, şiir ile edebiyatın kaynağı ve ilk aşaması olarak kabul edilebilir.?

Doğanın gizemlerini anlamada ve anlamlandırmada kutsal kitaplardan veya felsefî bilgilerden yoksun olmaları, İslam öncesi Araplarda anonim ve sözlü anlatım geleneğine dayalı mitolojinin daha yaygın ve etkin olmasının bir nedeni olarak görülebilir. Araplarda metafizik alanı dışında hastalığın tedavisinde, düşmana karşı zaferin elde edilmesinde, doğa felaketlerinden korunmada hatta en basit bir kararın alınmasında bile mitolojik yaklaşımlar görmek mümkündür. ${ }^{8}$

Dünyanın en köklü milletlerinden olan Türklerin kökü çoğunlukla

${ }^{4}$ Konu hakkında detay için bk. M. Fatih Duman, Kureyş kabilesi: İslam Öncesi Etnik, Siyasi ve Ekonomik Yapı (Mardin: Şırnak Üniversitesi Yayınları, 2017), 70-75.

5 Arap tarihi hakkında bilgi için bk. Hakkı Dursun Yıldız, "Arap" (tarih),Türkiye Diyanet Vakfi İslam Ansiklopedisi (İstanbul: TDV Yayınları, 1991), 3/272-276.

6 Halîl b. Ahmed el-Ferâhîdî, Kitâbu'l-ayn (Beyrut: Müessesetü'l-alem li'l-matbû'ât, 1988), 7/210-211; Ebu'1-Kâsım el-Hüseyn b. Muhammed Râgib el-İsfehânî, el-Müfredât fì elfâzi'Kur'ân (Dımaşk: Dârü'-kalem, 2002), 410.

7 Muhammed Abdülmuîd Han, el-Esâtîru'-Arabiyye kable'l-İslâm (Beyrut: Mektebetü'nnâfize, ts.), 11-12.

8 Klasik Arap inançları hakkında geniş bilgi için bk. Şemseddin Günaltay, İslam Öncesi Araplar ve Dinleri (Ankara: Ankara Okulu Yayınları, ts.) 
Hz. Nuh'un oğlu Yafes'e dayandırılır. ${ }^{9}$ Bilinen en eski yurtları Altay dağlarının kuzeyi ile Sayan dağlarının güneybatısı arasındaki bölgedir. ${ }^{10}$

İslam öncesi Türk mitolojisine bakıldığında genel olarak destanlarda bahsedilen ay, yıldız, su, ateş, ışık, demir ve bozkurt gibi belli başlı bazı simgelerin mitoloji öğesi olarak kullanıldığı görülür. Türk mitolojisinde su hayatın ve türeyişin kaynağı, demir kutsal gücün kaynağı, 1şık hayat veren özellikte bir olgu, kırk, yedi ve üç gibi sayılar ise önemli zaman ve olayları anlatmak için kullanılan mitolojik sayılardır. ${ }^{11}$

İslam öncesi Türk mitolojisi hakkındaki bilgilerin çoğu destanlardan elde edilmektedir. Son dönemlerde Türk mitolojisi alanında önemli akademik araştırmalar yapılmıştır. ${ }^{12}$ Orta Asya'dan göç edip Anadolu'ya yerleşmeleri ve eski inançlarından tamamen farklı olan İslam dinine girmeleri, Türklerin mitolojik inançlarının büyük ölçüde değişim geçirmesine neden olmuştur. Türkler mitolojinin en etkin alanı olan inanç alanında önemli ölçüde İslam dininden etkilenmiştir. Zira sosyal ve kültürel etkileşimin en doğal ve pratik yolu birlikte yaşama hailidir. Birlikte yaşamanın doğurduğu bu doğal etkileşim, Türklerin ve Arapların aynı inanca mensubiyetiyle daha da artmış ve her iki toplum arasında birçok ortak mitolojik unsurun ortaya çımasına zemin hazırlamıştır.

\section{TÜRKLERDE VE ARAPLARDA MITTOLOJIKK FİGÜRLER}

Türklerin ve Arapların metafizik anlamdaki mitolojik figürleri isim ve şekil açısından farklılık gösterse de bazı ortak noktalara sahiptir. Yaşam biçimlerinin kendilerine sağladığı derin tasvir yeteneği, Arapları metafizik güçleri görselleştirme eğilimine sevk etmiştir. Bu nedenle de tanrı olarak gördükleri varlıkları görselleştirip sembolleştirmişlerdir. ${ }^{13}$ Arapların sahip olduğu mitolojik inanç örneklerine Kur'ân'da da işaret edilmiş ve bazıları yerilmiştir. Yerilen bu tür mitolojik inançların başında melekleri tanrının kızları olarak tasavvur etmeleri (Nahl, 16/57) ve taş, altın, ağaç vb. mad-

9 Ahmet Taşağıl, "Türk", Türkiye Diyanet Vakfı İslam Ansiklopedisi (İstanbul: TDV Yayınları, 2012), 41/467-474.

${ }^{10}$ Mehmet Suat Bal, "Uygarlık Tarihi, Türk Uygarlı̆̆g", ed. İsmail Güven (Ankara: Pegem Akademi, 2010), 248.

${ }^{11}$ Türklerde sayıların mitolojik değeri hakkında geniş bilgi için bk. Bayram Durbilmez, "Kırım Türk Halk Anlatılarında Sayı Simgeciliği", Millî Folklor 76 (Kış 2007), 177-190.

12 Türk mitolojisi üzerine yapılan araştırmalar hakkında geniş bilgi için bk. Eda Aydın, Süreli Yayınlardaki Türk Mitolojisi Üzerine Yapılan Çalısmaların Halk Bilimi Açısından Değerlendirilmesi (İstanbul: İstanbul Üniversitesi, Sosyal Bilimler Enstitüsü, Yüksek Lisans Tezi, 2009).

${ }^{13}$ Ebu'l-Munzir Hişam b. Muhammed İbnu'l-Kelbî, Kitâbu'l-esnâm, thk. Ahmed Zeki Paşa (Kahire: Dâru'l-kutubi'l-Misriyye, 2000), 27. 
delerden şekillerini oluşturdukları putları kendileri ile tanrı arasında aracı olarak görmeleri (Zümer, 39/3) gelmektedir.

Arap mitolojisi birçok Müslüman ulusun mit anlayışına etki ettiği gibi Türk mitolojisine de etkide bulunmuştur. Zaman, yer, şahıs ve sayılar, etkileşimin en belirgin göründüğü alanlardır. Arap ve Türk mitolojisi karşılaştırıldığında yaygın olarak ortak bileşenlerin dinsel figürlerde olduğu görülür. Birçok Türk ve Arap mitolojik anlatıda sadece kahramanların isimlerinin ve olay yerinin değiştirilmesi ile hemen hemen aynı senaryoların varlığ $1^{14}$ bunun bir kanıtıdır. Her iki toplumun aynı dine inanmalarıyla başlamış olması nedeniyle Arapların İslam öncesi mitolojik figürlerinin Türklere yansıması ise yok denecek düzeydedir. Her iki toplumun ortak ve özgün mitolojik figürlerini altı başlıkta incelememiz mümkündür: ${ }^{15}$

\subsection{Tanrilar/Putlar}

Arap ve Türk toplumları tarafından 'tanrı' olarak görülen bazı figürler vardır. Türk ve Arapların mitolojik anlamda en çok çeşitliliğe sahip oldukları alan, inanç alanıdır. Arapların geneli kâinatta gelişen doğa olaylarının kaynağı olarak tanrıları görmekle beraber bu tanrıların niteliği ve mahiyeti hakkında farklı görüşlere sahiptirler. Kimi Araplar yaratıcıyı kabul etmekle beraber putları ona yardımcı olarak görürken kimisi de putları kendisini tanrıya yakınlaştıran aracılar olarak görürlerdi (ez-Zümer, 39/3). Bazıları da hayatın her aşaması için farklı bir putun görevlendirildiğini iddia eder ve her biri için ayrı bir sembol edinirlerdi. ${ }^{16}$

Köken olarak Budizm'in 'Buddha' kavramına dayanan ve 'but' olarak Farsçaya oradan da put şeklinde Türkçeye geçen bu kavram, "bilinçli ve canlı olduğuna inanılan sûret veya heykel, tamamen veya kısmen bir din̂ิ yapr içinde kurumsallaşmış ibadet konusu haline getirilmiş maddî obje, Allah'tan başka ilâh edinilen nesne" diye tanımlanabilir. ${ }^{17}$ İndiği dönemde Araplar arasında yaygın olan put olgusunu yoğun şekilde ele alıp eleştiren Kur'ân-1 Kerîm, bu kavramı ifade etmek için esnâm/sanem(En'ân, 6/74), ensâb/nusb (Mâide, 5/3,90), evsân/vesen (Hac, 22/30), cibt ve tâğūt (Nisâ, 4/51) gibi isim ve vasıflar kullanmıştır.

\footnotetext{
${ }^{14}$ Bu tür anlatılar için bk. Hüseyin Mecîd el-Mısrî, el-Üstûretu beynel-Arabi vel-Fursi ve't-Türk (Kahire: ed-Dâru's-sikâfiyye, ts.), 17-180.

15 Yedinci başlık olarak görülebilecek hayvan figürleri daha önce yayınlanan bir çalışmamızda ele alındığından tekrara düşmemek adına bu çalışmada ele alınmamıştır.

16 İbnu'l-Kelbî, Kitâbu'l-esnâm, 33.

${ }^{17}$ Ahmet Güç, "Put”, Türkiye Diyanet Vakfi İslam Ansiklopedisi (İstanbul: TDV Yayınları, 2007), 34/ 364-365.
} 
Putlar cahiliye dönemi Araplarının önemli bir figürüydü. Kabe'deki yaklaşık dört yüz putun yanı sıra her aileye özel putlar da bulunmaktaydı ${ }^{18} \mathrm{Ge}-$ nelde ağaç veya taşın yontulup şekillendirilmesi ile yapılan bu putların yakut ve altın gibi değerli madenlerden yapılanları da vardı. Kimi putları kendileri icat ederken kimilerini ise kendilerinden önceki kavimlerden miras almışlardı. Arapların Kur'ân'da da adları geçen meşhur tanrıları şunlardır:

Menât: Araplardaki üç tanrı inancından birisini teşkil eden Menât putu Medine'de yaşayan Araplarca kutsal addedilen önemli bir puttur. Siyah bir taştan insansı bir şekle büründürülen bu figür Araplar tarafından tanrının kızı olarak da telakki edilmiştir. Mekke ile Medine arasındaki Müşellel adlı bölgede bulunurdu. Bu put Araplarca kader tanrıçası olarak kabul edilmiştir.

Lât: Araplar nezdinde bereket tanrısı olarak kabul edilen bu put, coğrafi olarak kuzey Arabistan bölgesinde bulunurdu. Önde gelen üçlü tanrılardan biri olarak görülürdü. Hilal şekli, süt ve başak onun sembollerindendir. ${ }^{19}$

‘Uzzâ: Arapların güçlü ve önder olarak gördükleri üçlü tanrılardan biri olan 'Uzzâ, Tâif yakınlarında bulunurdu. Kendisine adak olarak insanlar dahi sunulurdu. Kutsallıkta Kabe'ye rakip konumunda bir tapınakta bulunur, aşkın ve ailenin koruyucu tanrısı olarak değer görürdü. Kureyşlîler tarafından da kabul görmüş bir puttur. Mekke'nin fethinden sonra Halit b. Velîd tarafından yıkılmıştır. ${ }^{20}$

Hübel: Yağmur, ticaret ve ziraat tanrısı olarak kabul edilmiştir. K1rık kolu altın bir kol ile tamamlanmıştır. İslamî döneme yakın kendisine olan ilgi yoğunlaşmıştır. Yanındaki hizmetlisi gözetiminde ok ve fal bakılır, ticaret ve evlilik gibi konularda görüşüne başvurulurdu. Bazı Araplar tarafından Hübel, Lât'ın çocuğu olarak kabul edilmiştir. Hübel peygamberimiz Hz. Muhammed'in babası Abdullah'ın kurban edilip edilmemesi olayında develer ile arasında huzurunda fal bakılan puttur. ${ }^{21}$

Vedd: Amr b. Luhay tarafından Mekke'ye getirildiği rivayet edilir. Kelb kabilesinin tanrısıdır. Suvâ', Yağûs, Ye'ûk ve Nasr isimli putlarda olduğu gibi Araplar Vedd putunu da Hz. Nuh kavminden tevarüs etmişlerdir (Nuh, 71/23). İnsan şeklinde tasvir edilen Vedd, savaş ve dostluk tanrısı

\footnotetext{
${ }_{18}$ İbnu'l-Kelbî, Kitâbu'-esnâm, 27; Muhammed b. Hişâm, es-Sîretu'n-nebeviyye, thk. Taha Abdurrauf (Kahire: Şirketu't-tibae, ts.), 72.

${ }^{19}$ Cevâd Ali, el-Mufassal fì târîhi'-Arab (Beyrut: Bağdat Üniversitesi Yayınları, 1993), 6/231.

${ }^{20}$ Bu putun yıkımı esnasında yaşandığ $ı$ iddia edilen olaylar hakkında dikkat çekici rivayetler bulunmaktadır. Detaylı bilgi için bk. Ebû Mansûr Abdullah b. Muhammed es-Se'âlibî, Simâru l-kulûb fi'l-mudâfi ve't-mansûb (Kahire: Dâru'l-ma'ârif, 1985), 23.

${ }^{21}$ İbn Hişâm, es-Sîretu'n-nebeviyye, 77.
} 
olarak kabul edilmiştir.22 Araplardaki put geleneğinin her evde bir putun bulunması boyutuna ulaştığı gerçeği göz önüne alındığında Araplardaki mitolojik put figürlerinin saydıklarımızdan ibaret olmadığı anlaşılacaktır.

Metafizik, İslam öncesi Türk toplumunda mitolojik unsurların en yaygın olduğu alanlardan biridir. İslam dinine girmeleriyle birlikte tevhit inancı benimsenmiş ve inanç konularında tevhit inancı ağır basmıştır. Ancak İslam öncesi Türk toplumunda tanrısal mitlerin varlığı azımsanmayacak düzeydedir. Türklerdeki yaratıcı veya herhangi bir konumda görevli olduklarına inanılan bazı mitolojik figürler bulunmaktadır. Yaygın olan figürlerden bazıları şunlardır:

Kara Han: Kara Han özellikle Altay Türklerinde gökyüzünün en yetkili ve etkili olan tanrısı olarak kabul edilir. İnanca göre tüm tanrıların atasıdır ve evrenin kaderini tayin eden tanrılar tanrısıdır. Dünyanın yaratılış ve yok oluş sürecinde ön planda olan tanrıdır. Göğün on yedinci katında oturduğu kabul edilen Kara Han, yeryüzünü yarattıktan sonra diktiği dokuz dallı çam ağacının her bir dalından bir ulusun türemesini istemiştir. ${ }^{23}$ Kara Han putlardan çok, Arapların putların yardımcısı olduğu ve kendilerini ona ulaştırdıklarını iddia ettikleri tanrı ile benzerlik arz eder.

ülgen: Kara Han'ın oğludur. Ay ve güneşin ötesinde babasının bir kademe altında göklerin on altıncı katında altından yapılma bir dağda oturur. Gök cisimlerinin yönetiminden yağmurun, gök gürültüsünün ve şimşeklerin işleyişindeki yetkili tanrıdır. Bu yönüyle Araplardaki Hübel putu ile ortak paydalara sahiptir. İnsanlara ateşi yakmayı öğreten odur. İyiliksever bir tanrı olan Gülgen, insan şeklinde tasvir edilir. Dünyayı taşımaları için üç balık yaratmıştır. Taşıdığı topuz, yaşam ağacının köklerini temsilen dallı budaklıdır. Kendisi şamanların ulaşamayacağı bir yerdedir. Sağında ve solunda iki ak güneş bulunur. ${ }^{24}$

Ak Ana: Yaratılış serüveni başlamadan ve her yer uçsuz bucaksız sudan oluşurken sudan çıkıp tanrı Ülgen'e yaratma ilhamı veren tanrıdır. Akabinde tekrar suya dalmıştır. Soyut bir beden olarak tasvir edilen Ak Ana hayatın başlangıç aşamasında varlıklara ruh bahşederek yaşam serüvenini başlatandır. ${ }^{25}$ İslam inancındaki sura üfleyen İsrâfîl' in rolüne benzer bir role sahip olduğu söylenebilir.

\footnotetext{
22 İbnu'l-Kelbî, Kitâbu'-esnâm, 50-53.

${ }^{23}$ Bahaeddin Ögel, Türk Mitolojisi (Ankara: Türk Tarih Kurumu, 2014), 165.

${ }^{24}$ Ülgen hakkında geniş bilgi için bk. Ramazan Volkan Çoban, “Türk Mitolojisinde İyilik Tanrısı Ülgen'in İnanıştaki Yeri, Tasviri ve Kökeni”, Bilim ve Kültür Dergisi 1/1 (Mart 2013), 192-198.

${ }^{25}$ Deniz Karakurt, Türk Mitoloji Ansiklopedisi (PDF: 2011), 44.
} 
Erlik Han: Temel ilkesi karşıtlığa ve aykırılığa dayanan mitolojide Erlik Han, iyiliksever ve merhametli tanrıların karşıtı olarak görülür ve kötülüğü temsil eder. Erlik kelime olarak kudretli, güçlü ve kuvvetli anlamlarına gelir. Erlik Han Altay Türklerinin inancına göre kötü ruhların başıdır. Şaman metinlerinde Erlik Han'a Kayrakan ifadesi de kullanılmıştır. Erlik Han insanların çektiği acıların ve ıstırapların kaynağıdır. Yer altı karanlık şehirlerinde farklı biçimlerde tasvir edilmiştir. İddiaya göre ikamet ettiği saray, insanların gözyaşlarından beslenen dokuz nehrin birleşerek oluşturduğu Toybodım nehri kenarındadır. Kendisine biçilen rollere bakıldığında Araplardaki iblis/şeytan figürünü çağrıştı̆̆ görülür. Saydığımız tanrı figürleri Türklerin mitolojisinde önde gelen figürlerdir. Bunların haricinde de farklı alanlardan sorumlu ve farklı yetkileri haiz tanrısal figürler bulunmaktadır. ${ }^{26}$

\subsection{Kâhinler/Şamanlar}

Kehanet, 'geleceğe dair öngörüde bulunmak, gelecekteki olaylarn sezinlemek ve bilinmeyen olayları aydınlığa çıkarmak' olarak tanımlanabilir. ${ }^{27}$ Bu eylemleri yapan veya yaptığını iddia edenlere de 'kâhin' denilir. ${ }^{28}$ Bu kavram günümüzde zihinlerde olumsuz bir anlam çağrıştırsa da kehanetin tüm türleri ile kötü olmadığını belirtmekte fayda vardır. Zira dönemin şartları göz önüne alındığında o dönemde kehanetin eldeki imkânlarla doğruya ve iyiye ulaşmada araç olarak da kullanıldığı söylenebilir.

Kâhinler Arap toplumunda gizli bilgilere, derin sezgilere ve olağanüstü güçlere sahip olduklarına inanılan seçkin bir zümreyi ifade eder. Bu nedenle kendilerinden çekinilir ve hışımlarına uğramamak için mümkün derece arzuları yerine getirilerek razı edilirlerdi. Toplumdaki temel rolleri danışmanlık ve rehberlik etmekti. Bu kâhinlerin çoğu aynı zamanda şair vasfına da sahiptiler. Kehanetin kullanım amacı toplumdan topluma farklılık gösterse de Araplar kehaneti başta kişilerin fizyolojik yapısına bakarak geleceğine dair öngörüde bulunmak, çocuğun soyunu tespit etmek, kararlaştırılması düşünülen eylemin sonuç itibarıyla olumlu veya olumsuz olacağına dair sezgide bulunmak ve ona göre karar vermek gibi amaçlarla kullanmışlardır. ${ }^{29}$

Araplardaki kâhinlerin yüklendiği misyon İslam öncesi Türk toplu-

${ }^{26}$ Geniş bilgi için bk. Karakurt, Türk Mitoloji Ansiklopedisi.

${ }^{27}$ Cemâluddîn Ebu'l-Fadl Muhammed b. Mukerrem b. Manzûr, Lisânu'-'Arab, thk. Amir Ahmed Haydar (Kahire: Dâru'1-kutubi'1-Arabiyye, 2009), 13/445.

${ }^{28}$ Ömer Faruk Harman, "Kâhin", Türkiye Diyanet Vakfi İslam Ansiklopedisi (İstanbul: TDV Yayınları, 2001), 24/170-171; İbn Manzûr, Lisânu'-'Arab, 13/446.

${ }^{29}$ Detaylı bilgi için bk. Mehmet Bölükbaşı, "Cahiliye Devrinde Araplarda Kehânet ve Kâhinlik", Nüsha: Şarkiyat Araştırmaları Dergisi 18/47 (2018), 127-148. 
munda şamanlar tarafından ifa edilmiştir. Şaman kelimesi 'ruhlardan esinlenen kişi' anlamını ifade eder. Şamanlar, Türklerin İslam dini ile tanışmalarının akabinde ozan ve âşık kisvesine bürünmüşlerdir. Türkler açısından bakıldığında Araplardaki kadar aktif ve yaygın bir kâhin zümresinin varlı̆̆ını iddia etmek söz konusu değildir. Ancak Türk toplumunda özellikle İslam öncesi dönemde ${ }^{30}$ geleceğe dair haber almak veya gizli bilgileri öğrenmek için başvurulan bir zümrenin varlığından bahsetmek mümkündür. $\mathrm{Bu}$ zümre 'şaman' olarak isimlendirilirdi. Türkler şamanları 'kâhin, bilge, filozof' anlamlarına gelen 'kam, baksi/bahşi' gibi isimlerle isimlendirirdi.

Altaylarda şamanlık veraset yolu ile babadan oğula geçerdi. Bu nedenle şaman olabilmek için şaman bir aileden gelmek şarttı. Şaman, atanın ruhu seçilen bir aile ferdine destek verir onu şaman olmak için destekler ve yönlendirirdi. Bu ruhun desteği olmadan şaman olmak ve kötü ruhlarla başa çıkmak mümkün değildir. ${ }^{31}$

İslam dininde gayb bilgisi sadece Allah'a ait bir olgu olarak kabul edilmiş (Neml, 27/65) falcılık yasaklanmış (Mâide, 5/90) ve peygamberimizin uyarısı ile kâhinlere inanmak ve onların söylemlerini doğru kabul etmek inkâr ile eşdeğer kabul edilmiştir. ${ }^{32}$ İslam'ın bu yaklaşımı neticesinde Araplardaki kâhinler önemlerini yitirdikleri gibi Türklerdeki şamanlar da önemini yitirmiştir.

Ancak İslam dini, Arapların ve Türklerin mit anlayışına aynı oranda etki etmediği gibi söz konusu toplumların kahinlik ve şamanlık müessesesi aynı akıma evirilmemiştir. Araplarda daha çok şairlik boyutu kalıcı olurken Türklerde ise halk ozanlığı ve âşıklık kurumuna evirildiğini söylemek mümkündür. Tüm boyutlarını kesinlikle kastetmeden tasavvufu her iki toplumdaki gelecekten haber verme mitinin İslami kisveye bürünmüş biçimi olarak görmenin mümkün olduğunu ileri sürebiliriz. Zira tasavvufta da keramet olgusu kabul gören bir durumdur.

\subsection{Cinler}

Cinler Araplar ve Türkler arasında mitolojik olarak yaygın kullanılan

\footnotetext{
${ }^{30}$ Harun Güngör, "Şamanizm”, Türkiye Diyanet Vakfi İslam Ansiklopedisi (İstanbul: TDV Yayınlar1, 2010), 38/325.

${ }^{31}$ Detaylı bilgi için bk. Ensar Aslan, "Şamanizm ve Şamandan Aşığa İntikal Eden Trans Olgusu', Halk Bilimi Dergisi/Motif Dergisi 2/3-4 (2009), 19-22.

${ }^{32} \mathrm{Bu}$ konuda birçok hadis bulunmaktadır. Bunlardan bir örnek vermek konunun anlașılması için yeterli olacaktır: Kim bir kâhine gider ve dediklerini tasdik ederse Muhammed'e indirileni inkâr etmiş̧ olur. Ebû Abdullah Muhammed b. İsmâîl, el-Buhârî, el-Câmiü's-sahîh, nşr. Mustafa Dîb el-Boğa (Beyrut: Dâru İbn Kesir, 1987), "İcâre", 20.
} 
figürlerden biridir. ${ }^{33}$ Cinler; 'duyularla algilanamayan, insanlar gibi idrak yetisine sahip, iyi ve kötüleri bulunan, gayb alemini bilen ve bazen insanlarla iletişime geçen varliklar' olarak bilinir. ${ }^{34}$ İnsanlarla olan iletişimlerine Kur'ân'da da (Neml, 27/39-40) Hz. Süleyman'ın Melike Belkıs'ın tahtını getirmesi olayında işaret edilir. Araplarda özellikle putların, şair ve kâhinlerin olağanüstü güçlerini cinlerden aldıklarına dair yaygın bir inanış vardır. Öyle ki bazı şiirlerin bizzat cinler tarafından söylendiğine inanılırdı. ${ }^{35}$ Buna yakın bir inanç olarak Türklerde de şamanların cinlerle bağlantılı olduğuna inanılmaktaydı. Şamanlar başta kötülük tanrısı Erlik olmak üzere kötü ruhlardan korunmak ve hastaları tedavi etmek için cinlerden yararlanırdı. ${ }^{36}$

Araplar cinleri sahip oldukları güç ve yeteneklerinin yanı sıra sergiledikleri davranışlarına göre İfrit, Şeytan, Amîr, Ğûl gibi farklı isimlerle de isimlendirirlerdi. ${ }^{37}$ Ayrıca farklı canlıların şeklinde tezahür etme yeteneğine sahip olduklarına inandıkları cinlerin genellikle yılan, köpek veya kedilerin suretine büründüklerine inanırlardı. ${ }^{38}$

Göçebe bir hayat yaşayan ve genelde tenha yerlerde hayatlarını sürdüren Araplarda cinlere dayalı mitolojik anlatılar azımsanmayacak derece yaygındır. Bununla bağlantılı olarak cinlere ait olduğu veya cinlerin uğrak yerleri olduğu iddia edilen birçok mekân bulunmaktadır. Bu mekânlara örnek olarak; Vâdil-abkar, Erdu vebâr, Hirkâne, Erdu'd-duvo ve Rimâlu'-hûş gibi yerleri göstermek mümkündür. ${ }^{39} \mathrm{Bu}$ düşünceler İslami kaynaklarda da varlığını sürdürmüştür. Nitekim birçok fıkıhçı Hz. Peygamberin arazi çatlaklarına işemeyi yasaklamasını söz konusu yerlerin cinlerin meskeni olmasıyla gerekçelendirmiştir. ${ }^{40}$

Mitlerin şekillenmesinde din algısının önemli bir rolü vardır. Bu nedenle Türk toplumunda İslam öncesi ve sonrası mit anlayışında belirgin farklar oluşmuştur. Cinler ve kötü ruhlar özellikle İslam öncesi Türk top-

${ }^{33}$ Geniş bilgi için bk. Nehhâd Tevfîk Ni`met, el-Cinnu fi't-edebil-arabiyyi (Beyrut: Amerika Üniversitesi, Edebiyat Fakültesi, Yüksek Lisans Tezi, 1960).

${ }^{34}$ el-İsfehânî, el-Müfredât, 204-205; M. Süreyya Şahin, "Cin”, Türkiye Diyanet Vakfı İslam Ansiklopedisi (İstanbul: TDV Yayınları, 1993), 8/4-5.

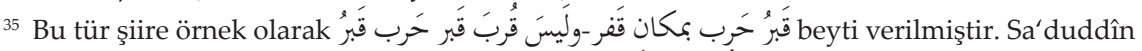
b. 'Umer b. 'Abdillâh et-Teftâzânî, Muhtasarưl-me'ânı̂' (İstanbul: Mektebetü'l-hâşimiyye, 2017), 42; Ahmed b. İbrâhim b. Mustafa el-Hâşimî, Cevâhiru'-belâga fi'l-me'ânî vel-beyân̂̂ ve'-bedî̀', thk. Yûsuf Sûmeylî (Beyrut: el-Mektebetü'l-asriyye, 2010), 32.

${ }^{36}$ Güngör, "Şamanizm", 325.

${ }^{37}$ Nehhâd, el-Cinnu fit-edebil-arabiyyi, 9-35.

${ }^{38}$ Nehhâd, el-Cinnu fit-edebil-arabiyyi, 7.

${ }^{39}$ Bu yerler hakkındaki mitler için bk. Usta, İslam Öncesi Arap Mitolojisi, 61-64.

${ }^{40}$ Takiyüddîn Ebû Bekr b. Muhammed el-Hüseynî el-Hısnî, Kifâyetül-ahyâr fî̀ halli Gâyetilihtisâr, thk. Abdulkâdir el-Arnâut- Tâlib Avvâde (Beyrut: Dâru'l-beşâir, 2001), 47. 
lumunda önemli bir yere sahiptir. Türk mitolojisinde cin ve şeytan figürlerine sıkça rastlanır. İnançlarına göre şeytanlar insanları sapıtmak ve kandırmak üzere Erlik Han emrinde görevlidirler. Temel görevleri fitne ve fesat çıarmak ve toplumu kötülüğe sevk etmektir. Şekil değiştirip insan veya herhangi bir hayvan şekline bürünme yetisine sahiptirler. Başlarında boynuzları bulunmaktadır. ${ }^{41}$

Şaman inancına göre bu dünyada kötülük yapan insanların ruhu bedenden ayrılıp yer altı aleminde kötülük tanrısı Erlik Han'ın boyunduruğuna girer. Bedenden ayrılan ruhların belli bir süre yeryüzünde başıboş gezindiklerine inanıldığından Altaylılar bu süre zarfında korku içerisinde yaşardı. Bu sürede başlarına kötü bir şeyin gelmesini bu ruhlara bağlar ve o yerden göç ederlerdi.

Türklerin İslam dini ile tanışmaları sonrasında cin ve şeytanlar hakkındaki yaklaşımları İslami düşünceyle uyumlu bir şekilde değişim geçirmiştir. İslam düşüncesine göre de Yüce Allah insanoğlundan önce cinleri yaratmıştır (Hicr, 15/26-27). Cinler tıpkı insanlar gibi erkek ve dişi cinsiyetine ve üreme yetisine sahiptirler (Rahmân, 55/55-56). İnanıp inanmamakta serbesttirler. Konuşur, yer ve içerler. ${ }^{42} \mathrm{Bu}$ varlıklar uzunca bir süre dünyada hakimiyet kurmuş, yaptıkları bozgunculuk nedeniyle tarumar edilerek dağlara sürülmüsslerdir. Dağ kovuklarını, kuytu, tenha, harabe, virane yerleri ve su kenarlarını mesken edinmişlerdir. ${ }^{43}$

\subsection{Kutsal Yerler}

Her toplum yaşadığı tarihi süreçte farklı nedenlerle kutsal addettiği bazı mekanlara sahiptir. Araplar da putların veya tapınaklarının olduğu mekanlara veya değer verdikleri bir önderin inşa ettiği bazı yapılara kutsallık atfetmişlerdir. Bunun en güzel örneği Arapların ve peygamberlerin atası olarak kabul gören Hz. İbrahim'in inşa ettiği Kâbe'dir. Bunun yanı sıra Sindâd, Ğumdân ile Riam tapınakları, Uzzâ ve Necrân hurmalıkları Araplarca kutsal görülen yerlerdir. İslam dini sonrasında da Arafat, Medine, Hira mağarası, Cudi ve Sevr dağları gibi yerler de kutsallık kazanmıştır. Türklerin İslam dini ile tanışmadan önce kutsal gördüğü yerlerin yanı sıra İslam dinine girmeleriyle kutsal kabul ettikleri mekanlar ortaya

\footnotetext{
${ }^{41}$ Detay için bk. Beydili, Türk Mitolojisi Ansiklopedik Sözlük, 28-32.

${ }^{42}$ Cinlerin özellikleri ve yaratılışları hakkında Kur'ân'da farklı yerlerde bilgiler verilmiştir. En detaylı ve derli bilgiyi Cin suresi 72. ayette görmek mümkündür.

${ }^{43}$ Ebû Muhammed b. Mes'ûd, b. Muhammed el-Bagavî, Me'âlimu't-tenzîl, thk. Abdurrezzak Mehdî (Beyrut: Dâru ihyâi't-turasi'1-Arabi, 1420/2000), 1/101.
} 
çıkmıştır. Hem Araplarda hem de Türklerde kutsal kabul edilen özgün mekanların yanı sıra ortak mekanların en önemlileri şunlardır:

Mekke: Mekke insanlık tarihinin eski yerleşim yerlerinden biridir. Kur'ân'da ilk mabedin (Kâbe) kurulduğu şehir olarak gösterilen Mekke'nin adı 'Bekke' olarak (Âli İmrân, 3/96) geçmektedir. Mekke şehri, kutsal mabet olan Kâbe ve bereketli zemzem suyu sayesinde Araplar nezdinde İslam öncesinde kutsal kabul edildiği gibi İslam sonrasında da kutsal kabul edilmiştir. İslam sonrasında da hac ibadetinin farz kılınmasıyla kutsallığı artmıştır. Bu açıdan bakıldığında Mekke'nin hem Türkler hem Araplar hem de tüm Müslüman toplumlar için önemli bir konuma sahip olduğu görülür.

Arafat Dağı: Arafat dağı Mekke'nin doğusunda yer alır. Hac ibadetinin en önemli unsurlarındandır. İslam öncesi Arap toplumunda da bilinen ve önemsenen bir mekandır. İnsanların atası Hz. Adem ile Havva'nın yeryüzüne atıldıktan sonra burada karşılaştığı kabul edilir. ${ }^{44}$ İslam sonrasında hac ibadetinin önemli bir rüknünün eda edildiği yer olmasıyla kutsall1ğı süreklilik kazanarak artmıştır.

Mescid-i Aksa: Hz. Davut tarafından yer tespiti yapılan ancak inşası oğlu Hz. Süleyman'a nasip olan Mescid-i Aksa aslında İslam diniyle tanışmadan önce hem Araplar hem de Türkler nezdinde çok tanınmamaktaydi. Ancak Hz. Peygamberin namazda bir müddet oraya yönelmesi ve İsrâ olayının içinde yer edinmesi, Müslümanların da bu mekânı kutsal olarak telakki etmelerine neden olmuştur. Bugün bile bu mekân hem ilk kıbleleri olması hem de Hz. Peygamber'in İsrâ yolculuğunda uğradığı yer olması nedeniyle Müslüman Arap ve Türklerde kutsal bir konuma sahiptir.

Yukarıda ele alınan mekânlar din kisvesiyle kutsallık kazanmış Müslüman Türk ve Arapların ortak kutsalıdır. Araplarda millı̂ ve ırka dayalı duygular gibi din harici bir bağ ile kutsallık kazanmış mekanlar çok nadirdir. Ancak Türklerde özellikle İslam öncesinde millî duygular ve nedenlerle kutsallık kazanan yerler bulunmaktadır. Bu durum, Arapların kabilecilik yaşam tarzına karşın Türklerin millî ve ırksal bağlantılara verdiği önemle izah edilebilir.

İslam öncesinde özellikle dağ kültü Türklerin inancında önemli bir yer tutmuştur. ${ }^{45}$ İslam dinine intisap etmeleri sonrasında İslam dünyasında kutsal görülen Arafat, Cudi ve Sevr dağı, Hira mağarası, Mekke ve Medine

${ }^{44}$ Abdullah A. Boks, "Arafat", Türkiye Diyanet Vakfi İslam Ansiklopedisi (İstanbul: TDV Yayınlar1, 1991), 3/263.

${ }^{45}$ Hikmet Tanyu, Dinler Tarihi Araştırmaları (Ankara: A.Ü. İlahiyat Fakültesi Yayınları, 1973), 28-32. 
gibi yerler Türklerde de kutsallık kazanmıştır. Kutsal yerler bağlamında bakıldığında Türklerde yerleşim yerlerinden ziyade dağların önemli bir yer tuttuğu görülür. Birçok dağ isminin tanrısal figürlerle ilişkili adlarla anılması da bunu destekler mahiyettedir. Dağlar tanrısal figürlerin meske$\mathrm{ni}^{46}$ olarak görüldüğü gibi yeryüzünü ağırlıklarıyla sabit tuttukları gerekçesiyle de kutsal görülür. ${ }^{47} \mathrm{Bu}$ bağlamda baktığımızda Türklerin önem atfedip mitolojik değer verdikleri dağların azımsanmayacak sayıda olduğu görülür. Dağlar Türk edebiyatında da önemli bir yer tutar. Nitekim birçok Türk atasözünde dağ temel özne olarak kullanılmıştır. ${ }^{48}$ Yaygın olarak bilinen bazı örnekler şunlardır:

Kaf Dağı: Türk/İslam mitolojisinin önemli motiflerindendir. Araplardan Türklere geçmiştir. ${ }^{49}$ Hakkında birçok mitolojik anlatılar bulunmaktadır. Yaygın kanaate göre tüm dünyayı çevreleyen, yeşil zümrütten yaratılmış bir dağdır. İklimler ve coğrafi bölgeler Kaf dağına göre ayarlanırdı. Zümrüdü Anka adlı mitolojik kuşun meskeni olarak bilinir. Adı olup kendisi olmayan bir figürdür. Ulaşılmazlı̆̆ın ve geçilmezliğin simgesidir.

\section{Altın Dă}

Türk mitolojisinin dağ figürleri arasında Altın dağın önemli bir yeri vardır. Altay Türklerin mitolojik anlatılarında sık kullanılır. İnanışa göre altın dağ gök kubbe altında som altından yapılan bir dağdır. Büyük tanrı Ülgen yeryüzünü yaratırken orda oturmuş ve yaratılışı buradan yönetmiştir. Bu dağın zirvesi hep güneşi görür geceyi yaşamazd..$^{50}$

\section{Ergenekon Dağ1}

Türk mitolojisi açısından Ergenekon dağı Araplardaki Kafdağı konumunda görülebilir. ${ }^{51}$ Ergenekon dağı Türk mitolojisinde özgürlüğün ve azmin sembolüdür. Rivayete göre Türk boyları arasında cereyan eden iç kargaşadan sağ kurtulan iki kadın ve iki erkeğin sığındığı yerdir. Kaostan çekinen bu insanlar, saklandıkları Ergenekon vadisinde zamanla çoğalıp önemli bir kitle haline gelirler. Etrafı Ergenekon dağlarıyla çevrili olan bu dar vadiye artık sığmayan Türkler vadiden çıkabilmek için çıkış yolu ararlar. Ancak

\footnotetext{
${ }^{46}$ Tanyu, Dinler tarihi, 37-38.

47 Tanyu, Dinler tarihi, 5-20. Dağların, ağırlıklarıyla dünyanın sabit kalmasına katkı sağladığı düşüncesi Kur'ân ayetinde de ifade edilmiştir. Bk. Nebe' 78/6-7.

48 'Dă̆ dă̆a kavuşmaz insan insana kavuşur. Dă̆ gibi adam. Fare dă̆a küsmüş dă̆ın haberi olmamış.' gibi söylemler bunu kanttlar mahiyettedir.

${ }^{49}$ Detay için bk. Beydili, Türk Mitolojisi Ansiklopedik Sözlük, 281-282.

50 Ögel, Türk Mitolojisi, 423.

51 Ögel, Türk Mitolojisi, 68.
} 
sarp dağlarda bir çıkış yolu yoktur. Farklı bir yol arayan Türkler dağdaki demiri eritip yol açmak için büyük bir ateş yakarlar. Bunun neticesinde eriyen demir sayesinde vadiden çıkmayı başarırlar. Ergenekon destanı Türklerin en zor şartlarda bile özgürlüğe olan düşkünlüklerinin bir sembolüdür. Anlatılan bu olay, Kur'ân'da konu edilen Zü'l-Karneyn kıssasındaki olay ile kısmi bir benzerlik arz etmektedir. Zira Kur'ân'da detaylıca anlatıldığı üzere Ye'cûc ve me'cûc toplumunun bozgunculuğundan ve saldırganlığından bıkan bir topluluk Zü'l-karneyn'den kendileri ile onlar arasında aşılmaz bir set inşa etmesini istemiş Zü'l-karneyn de onların isteğine uygun olarak aralarında aşılmaz bir şekilde demirden bir set yapmıştır (Kehf, 18/95-87).

\subsection{Zaman ve Sayılar}

Birçok toplumda olduğu gibi hem Araplarda hem de Türklerde bazı sayıların özel bir konuma sahip olduğuna dair bir inanç bulunmaktadır. Rakamlar Arap kültüründe sembolik olarak yaygın bir şekilde kullanılmıştır. Ebced hesabi ${ }^{52}$ günümüzde bile geçerliliğini ve cazibesini korumaktadır. İslam sonrasında hem tasavvuf hem de işârî tefsir alanlarında hurûfîlik olgusu ${ }^{53}$ yaygın bir kullanım alanına sahip olmuştur. Bu inancın arka planına bakıldığında rakamların ilişkilendirildiği birtakım olayların olduğu görülür. ${ }^{54}$ Örneğin yedi rakamı göklerin yedi kat oluşu, haftanın gün sayısının yedi oluşu, cennet ile cehennemin yedi tabakadan oluştuğu gibi olguları sembolize eder. Bu tür inanışlar İslam öncesi dönemde olduğu gibi İslam sonrası dönemde de önemini korumuştur. Nitekim inanışa göre Kur'ân yedi harf üzerine indirilmiş, gökler, cennet ve cehennem yedi kat olarak yaratılmıştır. Kâbe yedi defa tavaf edilir. Bir sayısına da Allah'ın birliğine işaret ettiği gerekçesiyle değer atfedilmiştir. Aynı şekilde ayların on iki olması ve benzeri nedenlerle on iki sayısı da kutsallık kazanmıştır. ${ }^{55}$

${ }^{52}$ Menşei Yahudilere dayanan ebced hesabı, İbrânîlerde rakam bulunmadı ğ için geliştirilmiş bir sistem olup hesaplamalar harflere değerler verilerek yapılıyordu. Ebced hesabı, daha sonra Müslümanlar tarafından çeşitli amaçlarla kullanılmıştır. Bilgi için bk. İsmail Yakıt, Türk İslâm Kültüründe Ebced Hesabr ve Tarih Düşürme (İstanbul: Ötüken Neşriyat, 1992); Mustafa Uzun, "Ebced", Türkiye Diyanet Vakfi İslam Ansiklopedisi (İstanbul: TDV Yayınları, 1994), 10/68-70.

${ }^{53}$ Hurûfîlik; Rakam ya da harflerle şifreleme yöntemi olarak özetlenebilir. Geniş bilgi için bk. Mehmet Emin Bozhüyük, "Hurûf", Türkiye Diyanet Vakfi İslam Ansiklopedisi (İstanbul: TDV Yayınları, 1998), 18/390.

${ }^{54}$ Detaylı bilgi için bk. Metin Özarslan, Mukhıdın Salkynbaev, Rauan Dossymbekova, "Şark Dünya Görüşüne Göre Kutsal Sayıların Oluşumu", Ankara Üniversitesi Dil ve Tarih coğrafya Fakültesi dergisi 54/2 (2014), 157-164.

${ }^{55}$ Detay için bk. Adnan Demircan, "İslam Kültüründe On İki Rakamı", İstem Dergisi 2/4 (2004), 9-34. 
Zaman kavramı da mitolojik olarak kayda değer bir önemi haizdir. Toplumlarda özellikle tarihlerini etkileyen olayların geliştiği veya önderlerin doğduğu ya da öldüğü veya dini bazı ritüellerin icra edildiği zaman dilimleri kutsal bir kisve kazanır. Araplarda da bu durum vaki olmuştur. Özellikle de İslam dinine geçişleri sonrasında Ramazan ay1 ${ }^{56}$, cuma günü ${ }^{57}$, peygamberimizin doğumu ve vefatı, bedir savaşı Mekke'nin fethi gibi tarihi olayların cereyan ettiği zaman dilimleri önem kazanmıştır.

Eski Türk inancı olan Şamanizm döneminde ve İslam sonrası dönemde Türk mitolojisinde bazı sayılar efsunlu ve tılsımlı kabul edilerek diğerlerinden ayrıcalıklı görülmüştür. Bu bazen olumlu bazen de olumsuz şekilde tezahür edebilmektedir. Nitekim kimi sayılar uğurlu görülürken kimi sayılar da uğursuz addedilmiştir. Örneğin on üç sayısı birçok insan tarafından uğursuz sayı olarak görülür. Bir, üç, beş, yedi, dokuz, on iki ve kırk gibi sayılar ise mitolojik anlamlara sahip kutsal sayılar olarak kabul edilmiştir. Özellikle Türklerin İslam dinine girmeleri ile başta bir sayısı olmak üzere bazı sayılar sembolik anlamlar kazanarak kutsal bir kisveye bürünmüştür. ${ }^{58}$

Bir sayısı Allah'ın birliğini temsil ettiği gibi toplumun kenetlenmesini, birlikteliğini ve düşmana karşı yekvücut olmayı temsil eder. Üç sayısı Şamanizm'de alemin üç bölümünü temsil ettiği gibi Karluk Türklerinin üç kolunu da temsil eder. İslam sonrası dönemde önemi kaybolmamış ve Türk kültürüne 'Allah'ın hakkı üçtür' sözüyle yansımıştır. Kız isteme, nişan ve düğün, yeni gelinlerin üç gün sonrasında baba evlerini ziyaret etmesi, ilk üç güne kadar kayın babası ve kaynanası ile karşı karşıya gelmemesi, İslam'da üç günden fazla küs kalmanın yerilmesi gibi günlük yaşamın birçok evresi, üç aşamadan oluşur.

Yedi sayısı da Türk mitolojisinin önemli rakamlarındandır. Altay Türklerine göre ayın tutulması, yedi başlı ejderha nedeniyledir. Soy göbeği ailede yediye kadar takip edilip bilinmelidir. Hafta yedi günden, gök yedi kattan oluşur. İslam sonrası dönemde yedi sayısı özellikle de 'Yedi uyurlar/Ashâbı Kehf' olayı ve yedi turdan oluşan tavaf gibi bazı dini ritüeller nedeniyle daha da önem kazanmıştır. Yedi sayısı günlük yaşamı-

\footnotetext{
${ }^{56}$ Ramazan ayının özellikle de Kadir gecesinin kutsallı̆̆ının ayette Kur'ân'ın inişi ile ilişkilendirilmesi, (Kadir, 97/1-5) zaman mefhumunun kutsallığının kendisinde cereyan eden olaylarla direkt ilişkisine bir örnek olarak görülebilir.

${ }^{57}$ Cuma'nın önemine dair hadis için bk. Ebu'l-Hasen el-Kuşeyrî b. Haccâc Muslim, Sahîhu Muslim, thk. Muhammed Fuâd 'Abdulbâkî (Beyrut: Dâru ihyâi't-turâsi'l-'Arabiyyi, ts.), "Cuma", 17-18, 27; "Taharet", 16.

${ }^{58}$ Özarslan, Salkynbaev ve Dossymbekova, "Şark Dünya Görüşüne Göre Kutsal Sayıların Oluşumu", 157-160.
} 
mızda 'yediden yetmişe, yedi ceddi gelse, yedi bela' gibi söz öbeklerinde vurgu amaçlı kullanılmaktadır.

Türklerde eskiden beri kutsal ve ayrıcalıklı görülen sayılardan biri de kırk sayısıdır. Bu Rakam Manas destanında kırk yiğit, kırk savaşçı, kırk gelin gibi ifadelerle yüzden fazla kez geçmektedir. İslam sonrasındaki dönemde de bu sayıya kutsal bakış artarak devam etmiştir. Bazı fıkıh mezheplerinde Cuma namazının farz olabilmesi için kırk kişinin olması zorunlu görülmüştür. ${ }^{59}$ Kırk sayısı birçok inançta önemli bir rakam olarak görülür. Nitekim Kur'an'da Hz. Musa'nın Tûr Dağı'nda kırk gün geçirdiği (A'râf, 7/143) açıça ifade edilmiştir. Ayrıca peygamberimizin de vahiy öncesinde Hira mağarasında kırk gün riyazette kaldığ 1 ve tasavvuftaki çilenin de bu olaylara atfen kırk günlük süreyle sınırlandırıldığını söylemek mümkündür. ${ }^{60}$ Günümüzde de ölünün kırkı çıkınca bir anma merasiminin düzenlenmesi bunun bir yansıması olarak görülebilir.

\subsection{Olağanüstü Güce Sahip İnsanlar}

Toplumların mitolojik unsurlardan biri de kendilerine olağanın dışında rol biçilen, değer atfedilen ve haklarında birçok mitolojik olaylar anlatılan efsanevi insanlardır. Bu insanlar genelde ahlaki değerlerle bilinen ve savaşlarda büyük kahramanlıklar göstermiş gerçek veya hayali kişilerden oluşmaktadır. Araplardaki bu şahsiyetlerin bir kısmı Kur'ân'da da zikredilmiştir. Bu anlatılardaki amaçlardan biri de kanaatimizce toplumdaki bireylerin motive edilerek benzer kahramanlıkları yapabileceklerine inandırma çabasıdır. Mitolojik anlatılarla çocuk ve gençlere rol model olarak sunulan kahramanlara bir özenti oluşturularak benzer hareket gösterme eğilimi oluşturulmasının amaçlanmış olduğunu söylemek mümkündür.

Türk ve Arapların ortak kahramanlarının yanı sıra her toplumun özgün bazı şahsiyetleri de vardır. Ortak kahramanlar İslam dini sonrasında ortaya çıkan figürlerdir. Arapların İslam öncesi mitolojik insan figürleri şunlardır:

Lokmân b. 'Âd: Araplar arasında bilgeliği uzun ömrü ve adaletiyle bilinen bu şahıs hakkında birçok rivayet bulunmaktadır. Kimisi onun Kur'ân'da adı geçen Hz. Lokman olduğunu iddia etse de genel kanaat bunun aksi yönündedir. ${ }^{61}$ Ömrü hakkında da farklı görüşler mevcuttur. Beş yüz, bin, hatta üç bin gibi abartılı rakamlar verenler olmuştur. ${ }^{62}$

${ }^{59}$ el-Hisnî, Kifâyetü'l-ahyâr, 163.

${ }^{60}$ Eraydin, Tasavouf ve tarikat, 139.

${ }^{61}$ Câhiz, el-Beyan ve't-tebyîn (Beyrut: Dâru ve Mektebetu Hilâl, 1423/2003), 1/123.

${ }^{62}$ Geniş bilgi için bk Usta, İslam Öncesi Arap Mitolojisi, 60-65. 
Zülkarneyn: Kur'ân'da adı geçen bu şahsın kim olduğu hakkında detaylı ve her kesim tarafından kabul gören bir bilgiye sahip değiliz. Kur'ân'da adil kişiliği ve yaptığı bir sefer hakkında özet bir bilgi mevcuttur (Bk. Kehf 18/83-110). Yunan krallarından Büyük İskender ile özdeşleştirenler olsa da konu netliğe kavuşmuş değildir. Kurân'da bahse konu edilen Zülkarneyn'in yaşam süresi hakkında farklı rakamlar verilmektedir. Oysa Yunanlı büyük İskender'in 36 yıl yaşadığı ve 13 yıl iktidarda kaldığı kabul edilmektedir. ${ }^{63}$

Seyf b. Zîyezen: Himyerlilerden soylu bir aileye mensuptur. Habeşlilerin Yemen'deki hakimiyeti esnasında özellikle de Ebrehe'nin oğlu Mesruk döneminde zulme maruz kalan Himyerlileri esaretten kurtarmıştır. Bu başarısı, etrafında birçok destansı olayın oluşmasına neden olmuştur. ${ }^{64}$ Peygamberimizin doğduğu dönemde vefat ettiği rivayet edilir. ${ }^{65}$

Dahhâk: Fiziki olarak varlığı hakkında ciddi şüpheler vardır. İnsan ve hayvan bileşiminden olduğuna dair iddialar mevcuttur. Bu figür Araplara mahsus bir mitoloji figürü değildir. Fars, Hint ve Ermeni kültüründe de yakın isimlerle izine rastlamak mümkündür. Yllan veya aslan şeklinde birden çok ağza ve göze sahip bir yaratık olarak tasvir edilir. İslam kültüründe zalim ve kötülügüü kaynağı bir figür olarak bilinir. Genelde anlatılarda Deccal ile yakın şekilde anlatılır. ${ }^{66}$ Araplarda haklarında özet mahiyetinde bilgiler verdiğimiz bu şahsiyetler dışında da birçok mitolojik figür bulmak mümkündür.

Her iki toplumunun ortak figürüne örnek olarak verilebilecek bazı şahsiyetler vardır. Bunların en önemlisi Battal Gâzî'dir.

Battal Gâzî: Endülüs'ten Orta Asya'ya kadar tüm İslam aleminde bilinen önemli bir mitolojik kahramandır. Hakkında değişik rivayetler bulunmaktadır. Emevîler döneminde özellikle Hıristiyan Bizans'a karşı gösterdiği kahramanlıklarla efsaneleşmiştir. Battal kahraman anlamında olup gösterdiği kahramanlıklar nedeniyle kendisine verilmiş bir lakaptır. Asıl adının Abdullah olduğu rivayet edilmiştir. Bazı kaynaklar dokuzuncu yüzyılda Malatya'da yaşadığını kaydetse de bunu ispatlayacak kanıt

\footnotetext{
${ }^{63}$ Ebu'1-Ferec Cemâluddîn 'Abdurrahmân b. 'Alî b. Muhammed İbnu'1-Cevzî, el-Muntazam fì târihi'l-mulûki ve'l-umem (Beyrut: Dâru'l-kutubi'l-ilmiyye, 1992), 1/428; Mustafa Öztürk, "Zülkarneyn", Türkiye Diyanet Vakfı İslam Ansiklopedisi (İstanbul: TDV Yayınları, 2013), 44/564-567.

${ }^{64}$ Bu olaylar hakkında geniş bilgi için bk. Ebu'1-Ferec, Kitâbu'l-eğân̂̂ (Beyrut: Dâru'1-kutubi'1ilmiyye, 2008), 17/308-310. Hüseyin Yazıc1, "Sîretü Seyf b. Zîyezen", Türkiye Diyanet Vakfı İslam Ansiklopedisi (İstanbul: TDV Yayınları, 2009), 37/271.

${ }^{65}$ İzzeddîn İbnü'1-Esîr, el-Kâmil fi't-târih (Beyrut: Dâru'1-kutubi'l-ilmiyye, 2010), 1/346.

${ }^{66}$ Kürşat Demirci, "Dahhâk", Türkiye Diyanet Vakfi İslam Ansiklopedisi (İstanbul: TDV Yayınları, 1993), 8/408.
} 
elimizde mevcut değildir. Battal gazi Türk coğrafyasında da sevilen ve efsaneleşen bir kahramandır. Türkler nezdinde veli-gâzî bir Alp eren kisvesinde düşünülmüştür. ${ }^{67}$ Günümüzde de Anadolu'da tanınan ve Türk sinemasında filmleri çekilen bir kahramandır.

\section{SONUÇ}

Aynı dine inanmanın ve birlikte yaşamanın milletlerin mitoloji anlayışları üzerindeki etkisini görmek amacıyla yapılan bu çalışmada ortak din, tarih ve kültüre sahip Türk ve Arap toplumları ele alınmış ve varılan bulgular aşağıda sıralanmıştır:

1. Her iki toplum yeni bir din ile tanışma evresi yaşamış ve bunun neticesinde özellikle teoloji alanında köklü bir mitolojik anlayış evrimi geçirmişlerdir.

2. Araplarda İslam öncesi devirde mitolojik figürler en çok tanrılar alanında oluşturulmuşken Türklerde daha çok milli duygular ve kabile bağları üzerinde kurgulanmış mitolojik anlatılar gelişmiştir.

3. İslam dini ile Araplardaki ve Türklerdeki birçok mitolojik inanç ortadan kalkmıştır. Ancak bazı âdetlerde ve deyimlerde geçmişin izlerini görmek mümkündür.

4. Araplarda şair ve kâhinlere yönelik hem mitolojik anlamda hem de toplumsal önderlik anlamında aşırı bir değer atfı gözlemlenirken bu değer atfı Türklerde yüzeysel kalmıştır.

5. İslam öncesi Araplarda sayılarda derinlemesine bir mitoloji gözlemlenmezken İslam sonrasında bazı sayılar önem kazanmıştır. İslam öncesi Türk mitolojisinde ise sayılar mitolojik bir değere sahiptir. İslam sonrasında sayılar özelinde Türklerde de Arapların yönelimine benzer bir yönelim ortaya çıkmıştır.

6. Araplarda ve Türklerde kutsal zaman ve mekân algısı İslam sonrasında daha da gelişmiş ve çeşitlenmiştir.

7. Günümüzde hem Arap hem de Türk toplumunun İslam öncesi mitoloji kalıntılarına rastlamak mümkündür. Anadolu'da duvarlarda geyik desenli resimlerin yaygın oluşu, günlük hayatımızda bazı rakamların ayrıcalıklı olduğunu gösteren deyim ve ifadeler, bunun birer kanıtı olarak görülebilir.

8. Son olarak Kur'an'ın şifreleri iddiasıyla modern dönemde bazı araştırmacıların rakamlardan yola çıkarak farklı anlamlar elde etme gayretine girmelerinin de geçmişin etkisi olarak kabul edilebileceğini söylemek mümkündür.

${ }^{67}$ Battal Gâzî’ nin hayatı ve hikâyeleri hakkında Geniş bilgi için bk. Ahmet Yaşar Ocak, “Battal Gazi", Türkiye Diyanet Vakfı İslam Ansiklopedisi (İstanbul: TDV Yayınları, 1992), 5/204-205. 


\section{KAYNAKÇA}

A. Boks, Abdullah. "Arafat". Türkiye Diyanet Vakfi İslam Ansiklopedisi. 3/261-263. İstanbul: TDV Yayınları, 1991.

Âlûsî, Cemâlüddîn Mahmûd Şükrî b. Abdillâh b. Mahmûd. Bulūğu'l-ereb fî ma'rifeti ahvâli'l-Arab. Beyrut: Dâru'l-kutubi'l-ilmiyye, 2009.

Aslan, Ensar. "Şamanizm ve Şamandan Aşığa İntikal Eden Trans Olgusu'. Halk Bilimi Dergisi/Motif Dergisi 2/3-4 (2009), 19-22. https://dergipark.org.tr/download/article-file/441899

Aydın, Eda. Süreli Yayınlardaki Türk Mitolojisi Üzerine Yapılan Çalışmaların Halk Bilimi Açısından Değerlendirilmesi. İstanbul: İstanbul Üniversitesi, Sosyal Bilimler Enstitüsü, Yüksek Lisans Tezi, 2009.

Bal, Mehmet Suat. Uygarlık tarihi, “Türk Uygarlı̆̆ı". ed. İsmail Güven. Ankara: Pegem Akademi, 3. Basım, 2010.

Bayat, Fuzuli. Mitolojiye Giriş. İstanbul: Ötüken Neşriyat, 2013.

Beydili, Celal. Türk Mitolojisi Ansiklopedik Sözlük. Ankara: Yurt Kitap Yayın, 2005.

Bozhüyük, Mehmet Emin. "Hurûf”. Türkiye Diyanet Vakfi İslam Ansiklopedisi. 18/390. İstanbul: TDV Yayınları, 1998.

Bölükbaşı, Mehmet. "Cahiliye Devrinde Araplarda Kehanet ve Kâhinlik”. Nüsha: Şarkiyat Araştırmaları Dergisi 18/47 (2018), 127-148. https://nusha.com.tr/wpcontent/uploads/2019/03/10.32330-nusha.471924-593493.pdf

Buhârî, Ebû Abdullah Muhammed b. İsmâîl. el-Câmiü's-sahîh. I-VI. nşr. Mustafa Dîb el-Boğa, Beyrut: Dâru İbn Kesir: el-Yemâme, 3. Basım. 1987.

Câhiz, Ömer b. Bahr. el-Beyân ve't-tebyîn. Beyrut: Dâru ve Mektebetu hilâl, 1423/2003.

Câhiz, Ömer b. Bahr. Kitâbu'l-hayevân. Beyrut: Dâru'l-kutubi'l-ilmiyye, 2011.

Can, Şefik. Klasik Yunan Mitolojisi. İstanbul: İnkilab Kitabevi, 1997.

Cevâd Ali. el-Mufassal fî târîhi'l-Arab. Beyrut: Bağdat Üniversitesi Yayınları, 1993.

Çoban, Ramazan Volkan . “Türk Mitolojisinde İyilik Tanrısı Ülgen'in İnanıştaki Yeri, Tasviri ve Kökeni". Bilim ve Kültür Dergisi 1/1 (Mart 2013), 192-198. https://docplayer.biz.tr/155860177-Turk-mitolojisinde-iyilik-tanrisi-ulgenin-inanistaki-yeri-tasviri-ve-kokeni.html

Demircan, Adnan. “İslam Kültüründe On İki Rakam”. İstem 2/4 (2004), 9-34. http:// isamveri.org/pdfdrg/D02535/2004_II_4/2004_II_4_DEMIRCANA.pdf

Demirci, Kürşat. "Dahhâk". Türkiye Diyanet Vakfı İslam Ansiklopedisi. 8/408. İstanbul: TDV Yayınları, 1993.

Duman, M. Fatih. Kureyş Kabilesi: İslam Öncesi Etnik, Siyasi ve Ekonomik Yapı. Mardin: Şırnak Üniversitesi Yayınları, 2017.

Durbilmez, Bayram. "Kırım Türk Halk Anlatılarında Sayı Simgeciliği”, Millî Folklor 19/76 (2007). 177-190. 
Ebhîşî, Şihâbuddîn. el-Mustadraf fì Külli Fennin Mustazraf. Beyrut: Dâru'l-kutubi'lilmiyye, 1992.

Ferâhîdî, Halîl b. Ahmed. Kitâbu'l-'ayn. Beyrut: Müessesetü'l-alem li'l-matbûât, 1988.

Güç, Ahmet. "Put”. Türkiye Diyanet Vakfi İslam Ansiklopedisi. 34/364-365. İstanbul: TDV Yayınları, 2013.

Günaltay, Şemseddin. İslam Öncesi Araplar ve Dinleri. Ankara: Ankara Okulu Yayınları, ts.

Güngör, Harun. “Şamanizm”. Türkiye Diyanet Vakfı İslam Ansiklopedisi. 38/325. İstanbul: TDV Yayınları, 2010.

Harman, Ömer Faruk. "Kâhin”. Türkiye Diyanet Vakfi İslam Ansiklopedisi. 24/170171. İstanbul: TDV Yayınları, 2001.

Hâşimî, Ahmed b. İbrâhim b. Mustafa. Cevâhiru'l-belâga fi'l-me'ânî ve'l-beyânî ve'lbedî’. thk. Yûsuf Sûmeylî. Beyrut: el-Mektebetü'l-asriyye, 2010.

Hüzelî, Ebu'l-Hasen Alî b. Hüseyn b. Alî el-Mes'ûdî. Murûcu'z-zeheb ve me'âdinu'lcevher. Beyrut: el-Mektebetü'l-asriyye, 1994.

İbn Manzûr, Cemâluddîn Ebu'l-Fadl Muhammed b. Mukerrem. Lisânu'-'Arab. thk. Amir Ahmed Haydar. b.y.: Dâru'l-kutubi'l-Arabiyye, 2009.

İbnu'l-Kelbî, Ebu'l-Munzir Hişam b. Muhammed. Kitâbu'l-esnâm. thk. Ahmed Zeki Paşa. Kahire: Dâru'l-kutubi'l-Mısriyye, 2000.

İbnu'l-Cevzî, Cemâluddîn 'Abdurrahmân b. 'Alî b. Muhammed. el-Muntazam fî târihi'l-mulûki ve'l-umem. Beyrut: Dâru'l-kutubi'l-ilmiyye, 1992.

İbnü'l-Esîr, İzzeddîn. el-Kâmil fi't-târih. Beyrut: Dâru'l-kutubi'l-ilmiyye, 2010.

İsfehânî, Ebu'l-Ferec. Kitâbu'l-eğânî. Beyrut: Dâru'l-kutubi'l-ilmiyye, 2008.

İsfehânî, Râgib. el-Müfredât fì elfâzi'l-Kur'ân. Dımaşk: Dârü'l-kalem, 2002.

Karakurt, Deniz. Türk Mitoloji Ansiklopedisi. PDF: 2011. https://turuz.com/storage/ Dictionary/2012/0575-Turk_Mitoloji_Ansiklopedisi-Achiqlamali-ResimliTurk_Soylence_Sozlughunun_Ansiklopedik_Versiyonu_(Deniz_Qaraqurt)_(2012).pdf

Misrî, Hüseyin Mecîd. el-Üstûretu beyne'l-Arabi ve'l-Fursi ve't-Türk. Kahire: edDâru's-sikâfiyye, ts.

Mihâil, Mesût. Esâtîr ve mu'tekedâtu'l-Arab kable'-İslâm. Beyrut: Dâru'l-ilm li'lmelâyîn, 1994.

Muslim, Ebu'l-Hasen el-Kuşeyrî b. Haccâc. Sahîhu Muslim. 5 Cilt. thk. Muhammed Fuâd 'Abdulbâkî. Beyrut: Dâru ihyâi't-turâsi'l-'Arabiyyi, ts.

Muhammed Abdülmuîd Han. el-Esâtîru'-Arabiyye kable'l-İslâm. Mektebetü'nnâfize, ts.

Muhammed b. Hişâm. es-Sîretu'n-nebeviyye. Beyrut: Dâru'l-kutubi'1-Arabiyyi, 1990.

Necatigil, Behçet. 100 Soruda Mitologya. 4. basım. İstanbul: Gerçek Yayınevi, 1988. 
Nehhâd Tevfîk Ni`met. el-Cinnu fil-edebil-arabiyyi. Beyrut: Amerika Üniversitesi, Edebiyat Fakültesi, Yüksek Lisans Tezi, 1960.

Ocak, Ahmet Yaşar. "Battal Gazi". Türkiye Diyanet Vakfi İslam Ansiklopedisi. 5/204205. İstanbul: TDV Yayınları, 1992.

Ögel, Bahaeddin. “Türklerde Kartal ve Kartal Arması”. Türk Kültürü dergisi (ordu sayısı) (Ağustos 1972), 1128-1146.

Ögel, Bahaeddin. Türk Mitolojisi. Ankara: Türk Tarih Kurumu, 2014.

Özarslan, Metin, Mukhıdın Salkynbaev, Rauan Dossymbekova. “Şark Dünya Görüşüne Göre Kutsal Sayıların Oluşumu”. Ankara Üniversitesi Dil ve TarihCoğrafya Fakültesi Dergisi 54/2 (2014), 155-166.

Öztürk, Mustafa. “Zülkarneyn”. Türkiye Diyanet Vakfi İslam Ansiklopedisi. 44/564567. İstanbul: TDV Yayınları, 2013.

Se’âlibî, Ebû Mansûr Abdullah b. Muhammed. Simâru'l-kulûb fi'l-mudâfi ve'l-mansûb. Kahire: Dâru'l-ma'ârif, 1985.

Şahin, M. Süreyya. “Cin”. Türkiye Diyanet Vakfı İslam Ansiklopedisi. 8/4-5. İstanbul: TDV Yayınları, 1993.

Takiyüddîn Ebû Bekr b. Muhammed el-Hüseynî el-Hısnî, Kifâyetül-ahyâr fî halli Gâyeti'l-ihtisâr. thk. Abdulkâdir el-Arnâut-Tâlib Avvâde. Dımaşk: Dâru'lbeşâir, 2001.

Tanyu, Hikmet. Dinler Tarihi Araştırmaları. Ankara: A.Ü. İlahiyat Fakültesi Yayınları, 1973.

Teftâzânî, Sa'duddîn b. 'Umer b. 'Abdillâh. Muhtasaru'l-me'ânî. İstanbul: Mektebetü'1-hâşimiyye, 2017.

Türk Dil Kurumu Sözlüğü. Erişim 13.10.2019. https://sozluk.gov.tr/

Usta, İbrahim. İslam Öncesi Arap Mitolojisi. Ankara: Ankara Okulu Yayınları, 2015.

Uzun, Mustafa. “Ebced”. Türkiye Diyanet Vakfı İslâm Ansiklopedisi. 10/68-70. İstanbul: TDV Yayınları, 1994.

Yakıt, İsmail. Türk İslâm Kültüründe Ebced Hesabı ve Tarih Düşürme. İstanbul: Ötüken Neşriyat, 1992.

Yazıcı, Hüseyin. "Sîretü Seyf b. Zîyezen". Türkiye Diyanet Vakfı İslam Ansiklopedisi. 37/271. İstanbul: TDV Yayınları, 2009.

Yıldız, Hakkı Dursun. "Arap" (tarih).Türkiye Diyanet Vakfı İslam Ansiklopedisi. 3/272276. İstanbul: Türkiye Diyanet Vakfı Yayınları, 1991.

Ziriklî, Hayruddîn. el-A'lâm. Beyrut: Dâru'l-'ilm li'l-melâyîn, 1984. 